\title{
ARE ROMANIAN TOURISM COMPANIES PREPARED FOR DIGITAL TRANSFORMATION? A RESEARCH STUDY IN TIMIS COUNTY
}

\author{
Marioara Musteață-Pavel ${ }^{\mathbf{1}}$, Camelia Surugiu ${ }^{2}$, Cristina Lixăndroiu ${ }^{3}$ \\ ${ }^{I}$ The National Institute of Research and Development in Tourism, Romania, pmioara@incdt.ro \\ ${ }^{2}$ University of Bucharest, Faculty of Business and Administration, Business Administration Department, \\ The National Institute of Research and Development in Tourism, Romania, camelia.surugiu@faa.unibuc.ro \\ ${ }^{3}$ The National Institute of Research and Development in Tourism, Romania, curea@incdt.ro
}

\begin{abstract}
Information and Communication Technology - ICT (i.e., computers and laptops, tablets, mobile phones, smartphones, software, audio-visual systems, wireless, VOIP, GIS, GPS, mobile app, analytical tools, augmented reality systems, holograms, virtual reality technologies) and-mainly - online information sources (multiplatform web pages, search engines, social media platforms) have changed how distribution, selling and consumption processes work. This also involved a revolution in how travel-related information is searched. Digital technologies have brought significant transformations to the tourism industry, significantly changing tourism business, products and destinations. The increase of digital platforms stimulated the variety and volume of tourism products, services and experiences. Nowadays, digital technologies are used as marketing tools by tourism companies, in order to boost efficiency and increase communication and awareness among visitors. The expansion of the Internet has supported the productivity of tourism-related applications and generated an opportunity for businesses to expand and attract more customers. Digitalization has changed the way tourist services are provided because customer expectations converge towards more digital solutions and tools. The present paper aims to investigate the online communication channels used by tourism organizations to promote businesses, products and services. The research was conducted in Timiș County, Romania, as a pilot study. The findings of the present paper provide valuable information regarding the limitation of digital marketing tools used by tourism companies and how to capitalize them as a strategic tool.
\end{abstract}

Keywords:

Digital marketing, tourism, communication, business promotion, ICT

JEL Classification: D83, Z33

DOI: $10.24818 / \mathrm{CTS} / 3 / 2021 / 2.02$

\section{Introduction}

The evolution and implementation of digital technologies significantly changed the way people work, travel and do business, and furthermore it transforms and reshapes tourism. The field of implementation and also adoption of digital technologies is different from one country, sector, organization, destination to another. The roles of producers and visitors changed due to digitalization, and thus new relationships, business models emerged (Dredge et al., 2018).

Digital technologies (i.e., websites, social media) also transformed the travel-related information search dynamics and distribution, selling and consumption processes. The search engines have created the connection between tourism business or tourism destinations and travellers in search for information and travel planning (Munar, 2012; Lee, Yoon and Park, 2017). The importance of digital technologies is great as they allow visitors to identify, customize and pay for tourism services. Furthermore, technological tools support organizational competitiveness, increase interconnectivity, reduce costs, support reliability and encourage effective implementation of strategy and operations (Bethapudi, 2013).

New digital technology trends also changed the profile of the visitors as they are not static anymore, just collecting information, but in return, they are creating, sharing, collaborating and communicating, thus

\footnotetext{
${ }^{*}$ contact author
} 
becoming more adaptive and flexible, searching for new experiences through social networking (Živković, Gajic and Brdar, 2014). Even though digital technologies are unequally used by tourism companies, the digital transformation proved to have a significant and intense impact on tourism. Digital transformation has an impact and generates opportunities not only on transactions, data on tourism supply and demand, but also on process information and communication (OECD, 2020).

Technologies may improve the quality of the marketing activities and strategies and substantially increase outputs. Tools such as social media, SEO, email, and paid media are frequently used by tourism companies to communicate better with customers. Digital technologies and digital marketing represent the challenge for tourism companies, nowadays and in the future. Tourism companies need to develop new skills, to adopt these digital technologies and to implement digital marketing strategies in order to be closer to the market and be able to adapt faster to a changing environment and versatile client.

The aim of the paper is to investigate the digital communication channels used by tourism companies to promote business, products and services provided to customers in Timiș County, Romania, as a pilot study. The paper is structured as follows. Next section presents the literature review on digital technologies' importance in the tourism field. Section three discusses the research methodology. Section four presents the research results. Last section concludes the paper.

\section{Literature review}

According to Gössling (2021, p.737) "where ICT turn into standards, business involvement is no longer a choice". Digital technologies generated an important change in the consumer behavior which modified business models. Haussmann and Weuster (2018) underlined that new technologies and digital communication tools allow tourism operators to come closer to customers and provide them customeroriented packages, also to better understand the younger target and to better react to novel challenges coming from all types of clientele. The level of digital communication tools used is not uniform across companies, because their mission, strategy, budget is different. Companies need to develop online communities for a better segmentation of the market (Mastorakis et al., 2015).

Pawłowska, Matoga and Stach (2015) emphasized that digital marketing expanded as a business tool in the tourism industry due to the increase in the Internet users all over the world, and now, not only companies should use digital technologies and ICT, but also public sector, local authorities and NGOs. New technologies are becoming highly important for travelers not only during the planning stage, but also during their stay in the visited locations, and thus tourism providers need to be able to endow with valuable information to them.

Nowadays, digital visitors look for recommendations and share information, videos and photos. Thus, tourism operators need to be more active in this regard and integrate tourists in multichannel communication and also encourage them to speak about their good experiences. In this way, tourism companies increase experiences and make them more personalized (Živković, Gajic and Brdar, 2014).

Tourism operators should develop their websites as their main marketing and communication tools through permanent updating of the website content, improvement of the website access and training (Vila, González and Darcy, 2018). Smart tourism websites represent an alternative for sharing information to tourists as they filter data and then provide accurate and updated, customized information. These proactively search for information implies data interflows among interrelated websites (Zhang, Cheung and Law, 2018).

Liberato, Alén-González and Liberato (2018) suggested that new technologies might be capitalized in the tourism industry in order to promote tourism businesses and destinations, to monitor tourist activities, to sell new and exciting tourism packages and to generate consumer knowledge. Tourism organizations might increase awareness and promote businesses through mobile apps, pop-ups, newsletters, websites and SEO strategies (Adeola and Evans, 2019).

eTourism technologies, such as social media tools, are dynamic, interactive, collaborative, consumercentric (Chuang et al., 2017), and this is the reason why tourism operators should focus more on their incorporation in current strategies and transform them into a competitive advantage. New technologies provide increasingly effective tools for analysing the behaviour of Internet users. However, thoughts, feelings and emotions have still remained insufficiently or not exploited at all. Thus, web 5.0 will 
become a tool for investigating and even exploiting human emotions. Web 5.0 marketing will aim to provide customers with a more personalized interaction, as well as a rich and a real-time experience (Mróz, 2016).

Digital marketing tools, such as websites or mobile apps enhance opportunities for local communities to participate in tourism activities and support tourism development. Digital content of tourism information limits the interaction between tourists and local communities and the knowledge-sharing is controlled (McGinnis, Harvey and Young, 2020).

\section{Methodology description}

The present research was conducted using a quantitative methodology, based on an online survey, selfadministered, applied in Timis County, as a pilot study. This online research among suppliers from Timis County's tourism industry, aimed to identify the communication channels used by organizations to promote their business, products and services.

The study was conducted through Google Forms online research platform. The research team administrated, by emails, 165 questionnaires to representative accommodation units, travel agencies, tourist information centers, tourist guides, the Association for Tourism Promotion and Development Timis, the West Regional Development Agency, etc. The research was conducted during April and May 2021. In the context of the COVID-19 pandemic (the tourism industry being one of the most affected), 24 organizations in the tourism industry participated in the survey, including accommodation structures, travel agencies, tourism associations, local authorities, regional development agencies, information centers. The response rate was $14.5 \%$.

The questions were divided into two categories. First section comprised questions about the profile of the respondent, using several identification data of the organizations, respectively the geographical location, the legal form, the number of employees. In the second section respondents provided some information about promotion in the online environment (i.e., the used communication channels, the allocation of a monthly budget for online communication). The authors presented and then discussed the key findings in percentage numbers, figures and graphs. All the research results in the analysis are based on the answers mentioned above.

\section{Results interpretation}

\subsection{Profile of the organization}

This section provides information related to the profile of the organizations that participated in the survey. An analysis of the main field of activity shows that nearly half $(41.7 \%)$ of the tourism organizations that participated to the survey are mainly involved in the accommodation services, followed by the activities of travel agencies and tour operators $(29.2 \%)$, tourist reservation service and related activities $(25.0 \%)$ and other $(4.1 \%)$. Most of the answers come from Timisoara $(62.5 \%)$, which is due to both the large number of organizations and their interest for this topic. Other respondents are from Bazosu Nou, Deta, Dumbravita, Lovrin, Luncanii de Jos, Margina, Mosnita Noua and Padureni.

The findings show that the majority of the surveyed tourism operators are Limited Liability Companies (62.5\%), followed by Authorized Individuals (12.5\%) and Individual Enterprises (8.3\%). In the "Other" category (16.7\%) the respondents specified: Public utility association, ROP Management Authority, Public Authority, Local Public Administration Organization.

In terms of the size of the company, defined by the number of employees, the results showed that most organizations (75.0\%) have less than 9 employees, $20.8 \%$ have between 10 and 49 employees and less than 5\%, between 101 and 249 employees. 
Table no. 1 Distribution of the sample

\begin{tabular}{|l|c|l|r|l|l|}
\hline Activity area & $\%$ & Legal form & $\%$ & $\begin{array}{l}\text { No. } \\
\text { employees }\end{array}$ & $\%$ \\
\hline $\begin{array}{l}\text { Hotels and other accommodation } \\
\text { units }\end{array}$ & 41.7 & Joint Stock Company (JSC) & 0.0 & $\begin{array}{l}1-9 \\
\text { employees }\end{array}$ & 75.0 \\
\hline $\begin{array}{l}\text { Activities of travel agencies and } \\
\text { tour operators }\end{array}$ & 29.2 & $\begin{array}{l}\text { Limited Liability Company } \\
\text { (LLC) }\end{array}$ & 62.5 & $\begin{array}{l}10-49 \\
\text { employees }\end{array}$ & 20.8 \\
\hline $\begin{array}{l}\text { Other tourist reservation service } \\
\text { and related activities (tourism } \\
\text { promotion activities - tourist } \\
\text { information centers, tourism } \\
\text { promotion associations, tourist } \\
\text { guides activities etc.) }\end{array}$ & 25.0 & Individual Enterprise (IE) & 8.3 & $\begin{array}{l}50-100 \\
\text { employees }\end{array}$ & 0.0 \\
\hline $\begin{array}{l}\text { Other } \\
\text { Total }\end{array}$ & 4.1 & $\begin{array}{l}\text { Authorized Physical Person } \\
\text { (APP) }\end{array}$ & 12.5 & $\begin{array}{l}101-249 \\
\text { employees }\end{array}$ & 4.2 \\
\hline Other & $\mathbf{1 0 0}$ & & 16.7 & $\begin{array}{l}\text { over 250 } \\
\text { employees }\end{array}$ & 0.0 \\
\hline
\end{tabular}

Source: processed by authors

\subsection{Online presence of tourism organizations}

The present survey aimed to identify the digital technologies currently used by tourism organizations from Timis County in their daily activities. The findings show that website and social media channels (Facebook, Instagram, Pinterest, YouTube, etc.) are the most common communication channels (83.3\%) used by organizations in Timis County to promote their business, products and services. Tourism operators also use marketing emails / newsletters (54.2\%), e-commerce / booking and review sites (Booking, Tripadvisor, Airbnb, etc.) (41.7\%), traditional advertising (33.3\%) and tourism fairs $(29.2 \%)$.

The websites give companies more control over the content delivered, and website visitors are already involved when accessing them. Social networks provide effective promotional tools that allow targeting and conversion of the target audience. The earnings from these promotional tools are also important, and companies continue to invest in their use. The emails and the newsletters have become less effective in recent years, as people are accustomed to many daily emails, and their rate of opening and response is becoming lower.

Table no. 2 Communication channels

\begin{tabular}{|l|c|c|}
\hline Answer options (multiple choice question) & Percentage & Frequency \\
\hline Own website & 83.3 & 20 \\
\hline Tourism blog & 0.0 & 0 \\
\hline Email/newsletter & 54.2 & 13 \\
\hline Social media channels (Facebook, Instagram, Pinterest, YouTube, etc.) & 83.3 & 20 \\
\hline E-commerce / booking and review sites (Booking, Tripadvisor, Airbnb, etc.) & 41.7 & 10 \\
\hline Mobile messaging (SMS) & 16.7 & 4 \\
\hline Tourism Fairs & 29.2 & 7 \\
\hline Traditional advertising (billboards, radio, TV, press) & 33.3 & 8 \\
\hline Other & 4.2 & 1 \\
\hline Total & $\mathbf{1 0 0}$ & $\mathbf{2 4}$ \\
\hline
\end{tabular}

Source: processed by authors

The survey's results show that $41.7 \%$ of the organizations has a digital marketing strategy or a plan. Depending on the main field of activity, the accommodation units and the travel agencies are the sectors that most frequently mentioned this digital marketing strategy or plan. 
Table no. 3 Digital marketing strategy or plan

\begin{tabular}{|l|c|c|}
\hline \multicolumn{1}{|c|}{ Answer options } & Percentage & Frequency \\
\hline Yes & 41.7 & 10 \\
\hline No & 58.3 & 14 \\
\hline Total & $\mathbf{1 0 0}$ & $\mathbf{2 4}$ \\
\hline
\end{tabular}

Source: processed by authors

Regarding the extent to which organizations use different digital marketing channels to communicate with customers (on a scale from 1 to 5), Facebook obtained the highest score (3.8), followed by the own website (3.6) and reservation and review websites (3.1). On the other side, Timis County organizations have reported low usage of Facebook Watch and Instagram TV (1.1) and TikTok (1). Thus, digital marketing channels have a relatively uniform distribution of the score that can be clustered in three groups of importance:

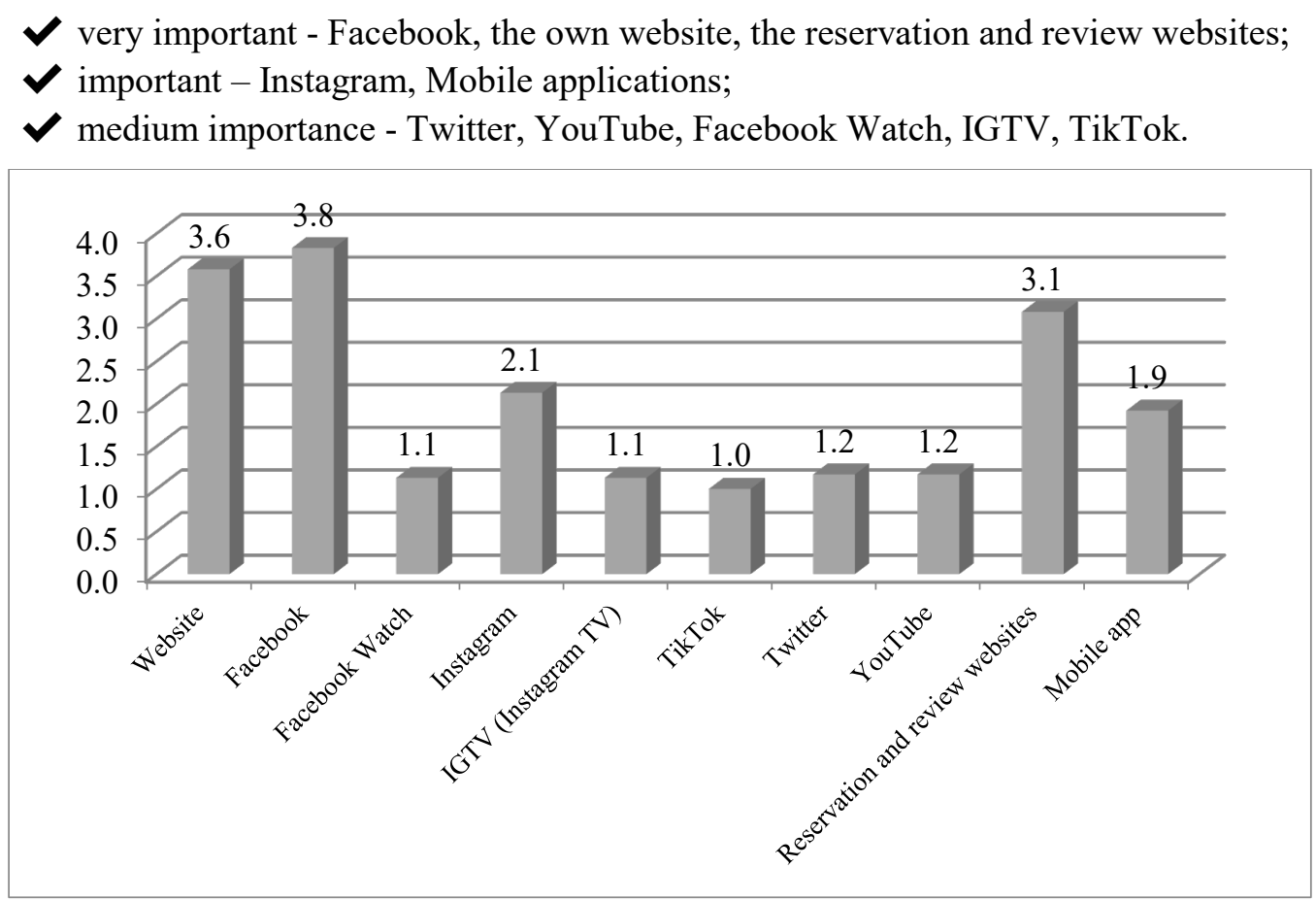

Fig. no. 1: Frequency of digital tools for business promotion Source: processed by authors

Most tourism organizations (70.8\%) mentioned that they do not allocate a monthly budget for digital marketing. Of the organizations that invest in online promotion $(29.7 \%)$, a large majority of them (71.4\%) allocated less than 500 Euros / monthly to online campaigns, while $14.3 \%$ spent between 500 and 1,000 Euros. The tourism content promoted through social media did not require a high financial effort for the organizations, being often a much cheaper solution than the traditional marketing activity.

Table no. 4 Digital marketing budget

\begin{tabular}{|l|c|c|}
\hline Answer options & Percentage & Frequency \\
\hline Less than 500 Euros & 71.4 & 5 \\
\hline $500-1,000$ Euros & 14.3 & 1 \\
\hline $1,000-3,000$ Euros & 0.0 & 0 \\
\hline More than 3,000 Euros & 0.0 & 0 \\
\hline I don't know & 14.3 & 1 \\
\hline Total & $\mathbf{1 0 0}$ & $\mathbf{7}$ \\
\hline
\end{tabular}

Source: processed by authors

The collected data show that the main communication tools used regularly to increase visibility are: Facebook Ads (71.4\%), personalized offers by email / newsletter (71.4\%), Google Ads (42.9\%), SEO 
(28.6\%). However, YouTube, E-Commerce and Waze and Google Maps ranked the lowest (14.3\%), while other communication tools (such as Instagram Ads and SEM) recorded $0 \%$ usage.

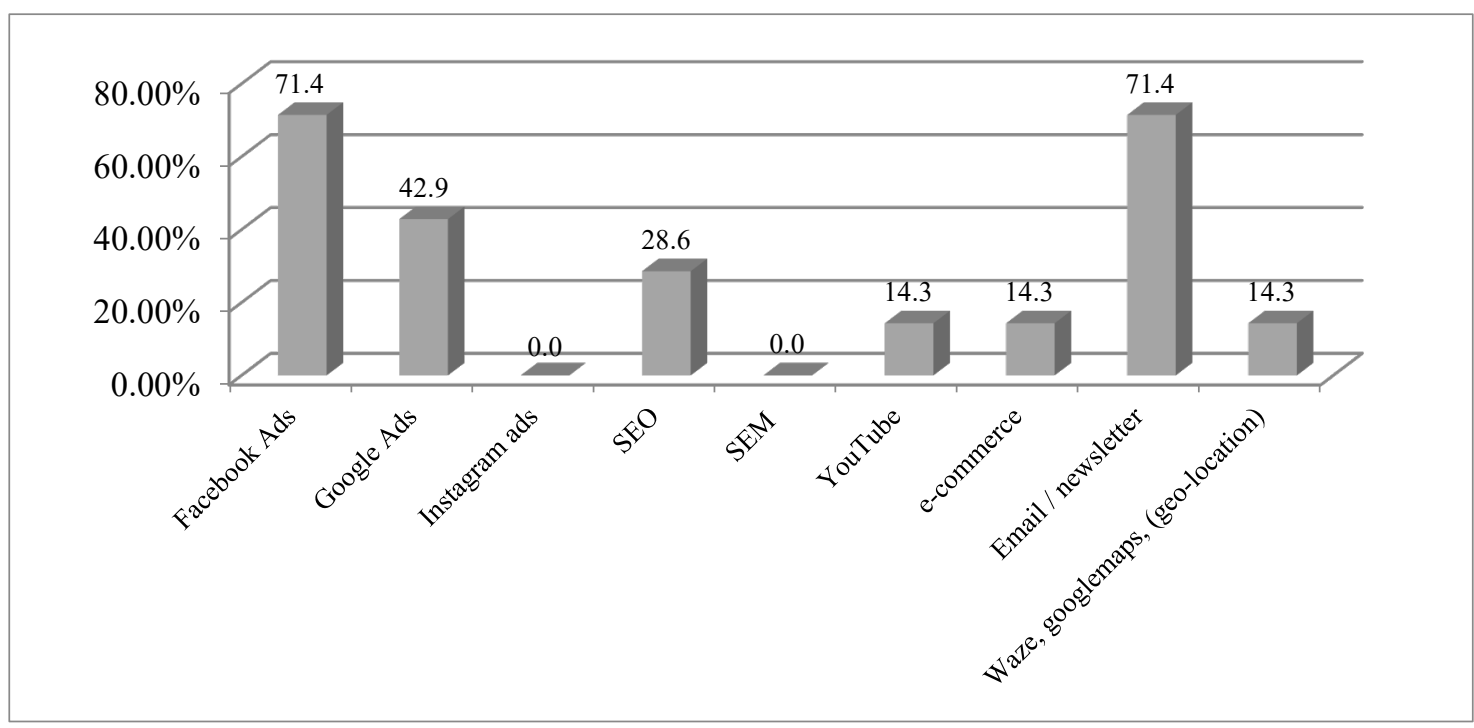

Fig. no. 2: Communication tools used to increase visibility

Source: processed by authors

In terms of managing the online presence, the most common approach is to have a marketing department $(25 \%)$ or to use the services of a communication agency or a consultant $(25.0 \%)$. Only $8.3 \%$ of the organizations have a special department or specialized staff dedicated to online communication with customers or a human resources department. $41.7 \%$ of the organizations mentioned "other" options, namely the administrator, the manager, the Cultural and Tourist Promotion Office or the tourist guide are in charge of managing their online presence.

Table no. 5 Management responsibility for online presence of the company

\begin{tabular}{|l|c|c|}
\hline Answer options (multiple choice question) & Percentage & Frequency \\
\hline Marketing department & 25.0 & 6 \\
\hline $\begin{array}{l}\text { A special department / specialized staff dedicated to online communication with } \\
\text { customers / tourists }\end{array}$ & 8.3 & 2 \\
\hline IT department & 0.0 & 0 \\
\hline Human resources department & 8.3 & 2 \\
\hline We use the services of a communication agency or a consultant & 25.0 & 6 \\
\hline Other & 41.7 & 10 \\
\hline Total & $\mathbf{1 0 0}$ & $\mathbf{2 4}$ \\
\hline
\end{tabular}

Source: processed by authors

Regarding the interaction with tourists, $87.5 \%$ of the organizations reported that they use online communication before visit (booking, promotion), 75.0\% during visit (to facilitate certain services guidance, payment, booking certain services, presentation of the offers / products) and $75.0 \%$ after visit (loyalty, review, survey regarding the quality of the services offered).

Table no. 6 Interaction with tourists during online communication

\begin{tabular}{|l|c|c|}
\hline Answer options (multiple choice question) & Percentage & Frequency \\
\hline Before visit & 87.5 & 21 \\
\hline During visit & 75.0 & 18 \\
\hline After visit & 75.0 & 18 \\
\hline Total & $\mathbf{1 0 0}$ & $\mathbf{2 4}$ \\
\hline
\end{tabular}

Source: processed by authors

A high percentage of the organizations considered that the online environment has a large $(58.3 \%)$ and very large $(41.7 \%)$ influence on communication with their customers. 
Regarding the evaluation tools of the success of the digital marketing efforts, the majority of the organizations $(62.5 \%)$ mentioned free analytics tools, followed by the reports produced by the organization $(20.8 \%)$. Only $8.3 \%$ of the organizations used a paid analytics tool or reports made by a consultant.

Table no. 7 Digital marketing evaluation tools

\begin{tabular}{|c|c|c|}
\hline Answer options (multiple choice question) & Percentage & Frequency \\
\hline Using a free analytics tool & 62.5 & 15 \\
\hline Using a paid analytics tool & 8.3 & 2 \\
\hline Using the reports produced by the organization & 20.8 & 5 \\
\hline Using the reports made by a consultant & 8.3 & 2 \\
\hline Using an external e-commerce platform / software & 4.2 & 1 \\
\hline Other (not measured) & 8.3 & 2 \\
\hline Total & 100 & 24 \\
\hline
\end{tabular}

Source: processed by authors

Among the channels considered the most effective or that would provide the best return on investment (ROI) for the digital marketing strategy, the organizations mentioned first the social networks $(87.5 \%)$ and then the organization's website (75.0\%). Other relevant channels are the emails $(25.0 \%)$, the mobile application (25.0\%), the online videos (20.8\%), the electronic billboards (20.8\%), the paid search $(8.3 \%)$ and the native ads $(4.2 \%)$.

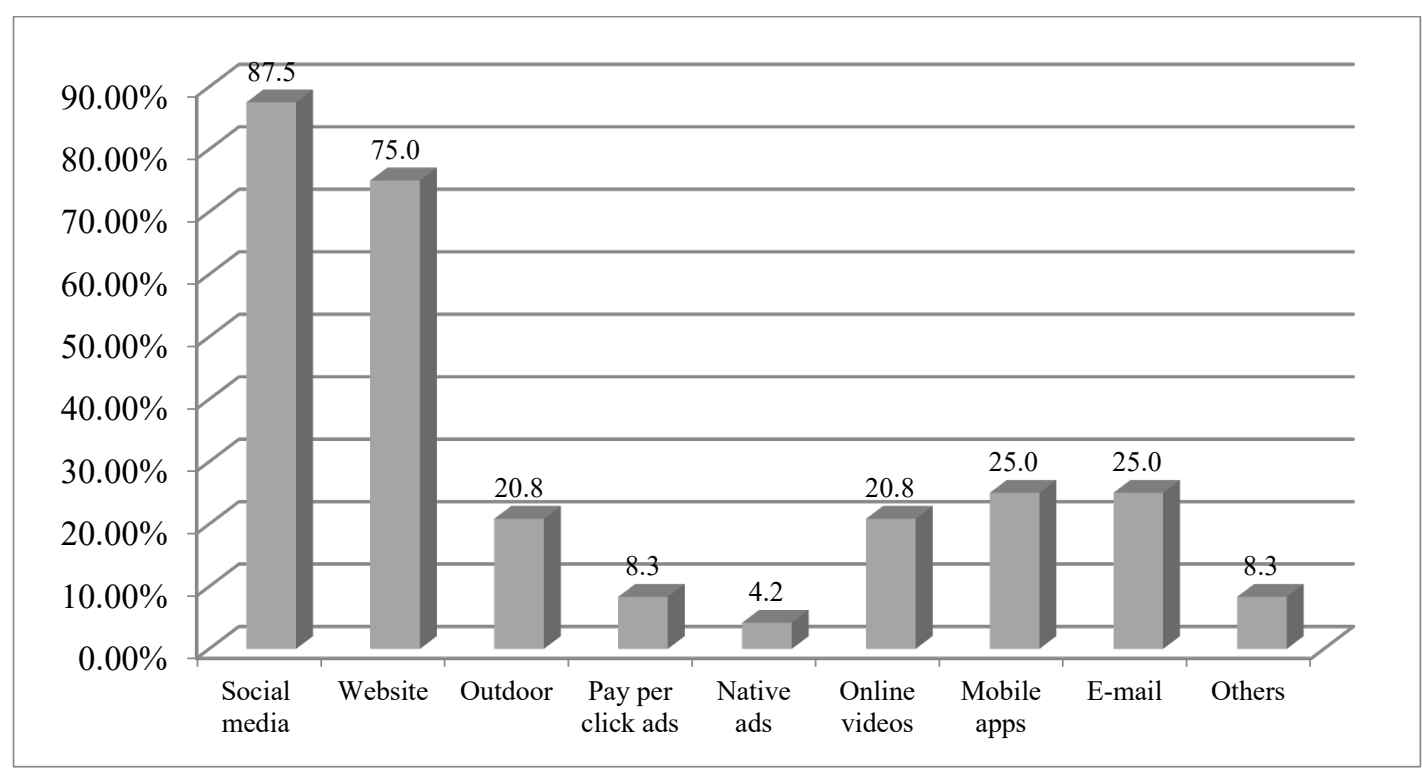

Fig. no. 3: Most efficient digital marketing tools Source: processed by authors

Tourism is a key component of the economy of Timis County and will continue to be in the future. A major transformational force in the tourism sector is the digital economy, which is leading a new phase of growth and development in European tourism regions.

\section{Conclusions}

The customer expectations have increased the pressure for companies to be present on many digital channels, offering personalized and positive experiences on each of them. To keep up with these expectations, digital marketing goals have gone beyond simply raising brand awareness and now include managing customer relationships throughout the acquisition cycle. The providers are not totally aware of the huge potential the digital tools and digital marketing provide to visitors. From the management side, ICT and digital technologies have a significant impact on the development of the businesses and the destinations as they increase connectivity and expand knowledge (Haussmann and Weuster, 2018). 
Successful implementation of digital marketing tools depends extensively not only on the budget allocation but also on the collaboration between departments, professional organizations, organizational change and a customer-focused approach throughout businesses.

This research on the digital marketing tools employed by tourism companies from Timis County, showed that the majority of the responding organizations are relatively conservative in their business approaches and there are different attitudes and challenges regarding digitalization in tourism. Organizations may see opportunities, particularly in terms of more effective business practices and market expansion, and they are motivated to implement digital solutions to increase their competitiveness, to develop and to expand their networks. Digital innovation will certainly remain a long-term marketing trend in the post-pandemic world and a way to inform digital strategies to accelerate the recovery of tourism.

Nowadays, tourism businesses and local authorities need to adjust their online information content. Businesses seem to have the highest implication in the implementation of digital technologies in the communication activity, because of the commercial dimension of their activity and the necessity to sell their products and services (Pawłowska, Matoga and Stach, 2015). Thus, tourism companies need to embrace this digital transformation and implement digital marketing tools to increase connection, communication with customers and support brand awareness.

\section{References}

Adeola, O., Evans, O., 2019. Digital tourism: mobile phones, internet and tourism in Africa, Tourism Recreation Research, 44(2), p. 190-202, DOI: 10.1080/02508281.2018.1562662

Bethapudi, A., 2013. The Role of ICT in Tourism Industry, Journal of Applied Economics and Business, 1(4), pp. 67-79.

Chuang, T., Liu, J., Lu, L., Tseng, F.M., Lee, Y., Chang, C.T., 2017. The main paths of eTourism: trends of managing tourism through Internet, Asia Pacific Journal of Tourism Research, 22(2), pp. 213-231.

Dredge, D., Phi, G., Mahadevan, R., Meehan, E. \& Popescu, E.S., 2018. Digitalisation in Tourism: In-depth analysis of challenges and opportunities. Low Value procedure GRO-SME-17-C-091-A for Executive Agency for Small and Medium-sized Enterprises (EASME) Virtual Tourism Observatory. Aalborg University, Copenhagen.

Gössling, S., 2021. Tourism, technology and ICT: a critical review of affordances and concessions, Journal of Sustainable Tourism, 29(5), pp. 733-750, DOI: 10.1080/09669582.2021.1873353

Hausmann, A., Weuster, L., 2018. Possible marketing tools for heritage tourism: the potential of implementing information and communication technology, Journal of Heritage Tourism, 13(3), pp. 273-284, DOI: $10.1080 / 1743873 X .2017 .1334786$

Lee, M.K., Yoon, H. Y., Park, H.W., 2017. From online via offline to online: how online visibility of tourism information shapes and is shaped by offline visits, Journal of Travel \& Tourism Marketing, 34(9), pp. 1143-1154.

Liberato, P. M., Alén-González, E., Liberato, D.F.V., 2018. Digital Technology in a Smart Tourist Destination: The Case of Porto, Journal of Urban Technology, 25(1), pp. 75-97, DOI: 10.1080/10630732.2017.1413228

Mastorakis, G., Trihas, N., Perakakis, E., Kopanakis, I. 2015. E-CRM in tourism exploiting emerging information and communication technologies, Anatolia: An International Journal of Tourism and Hospitality Research, 26(1), pp. 32-44, DOI: 10.1080/13032917.2014.902767

McGinnis, G., Harvey, M., Young, T., 2020. Indigenous Knowledge Sharing in Northern Australia: Engaging Digital Technology for Cultural Interpretation, Tourism Planning \& Development, 17(1), pp. 96-125, DOI: $10.1080 / 21568316.2019 .1704855$

Mróz, B., 2016. New Information Technologies: Implications for Business Strategies and Marketing Communication, in The Impact of the Digital World on Management and Marketing, eds. Mazurek, G., Tkaczyk, J., Poltext Co. Ltd, Warsaw, pp. 125-140.

Munar, A.M., 2012. Social Media Strategies and Destination Management, Scandinavian Journal of Hospitality and Tourism, 12(2), pp. 101-120. 
Pawłowska, A., Matoga, L., Stach, E., 2015. The Use of Information and Communication Technologies (ICTs) in Tourist Information and Promotion of the Polish Carpathians in Foreign Tourism Markets, Journal of Travel \& Tourism Marketing, 32(5), pp. 554-577, DOI: 10.1080/10548408.2014.918926

OECD, 2020, "Foreword", in OECD Tourism Trends and Policies 2020, OECD Publishing, Paris, https://doi.org/10.1787/5ac07b74-en.

Vila T.D., González, E.A., Darcy, S., 2018. Accessible tourism online resources: a Northern European perspective, Scandinavian Journal of Hospitality and Tourism, 19(2), pp. 140-156, DOI: $10.1080 / 15022250.2018 .1478325$

Zhang, T., Cheung, C., Law, R., 2018. Functionality Evaluation for Destination Marketing Websites in Smart Tourism Cities, Journal of China Tourism Research, 14(3), pp. 263-278.

Živković, R., Gajic, J., Brdar, I., 2014, The Impact of Social Media on Tourism, Sinteza, E-Business in tourism and hospitality industry, pp. 758-761 